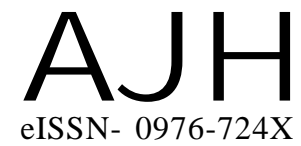

Received : 19.01.2016

Revised : 27.04.2016

Accepted : 06.05.2016

Members of the Research Forum

Associated Authors:

${ }^{1}$ Department of Fruit Crops,

Horticultural College and Research

Institute, Tamil Nadu Agricultural

University, COIMBATORE (T.N.)

INDIA
Author for correspondence : C.V.SHALINI UDAYA

Department of Fruit Crops,

Horticultural College and Research

Institute, Tamil Nadu Agricultural

University, COIMBATORE (T.N.)

INDIA

Email : shalini.udaya@gmail.com
THEASIAN JOURNALOF HORTICULTURE

Volume 11 | Issue 1 | June, 2016 | 141-145

Visit us -www.researchjournal.co.in

RESEARCH PAPER

DOI : 10.15740/HAS/TAJH/11.1/141-145

\section{Enhancing propagation efficiency of banana cv. MONTHAN (ABB) through micropropagation}

\author{
C.Y. SHALINI UDAYA, H.K. PORIKA ${ }^{1}$, V. SINDHUPRIYA ${ }^{1}$ AND P. \\ PRASANNA KUMAR ${ }^{1}$
}

ABSTRACT : An investigation was carried out at Plant Tissue Culture Laboratory of Horticultural College and Research Institute, Coimbatore during 2012-2013. Shoot tip of banana cv. MONTHAN were cultured in MS medium fortified with different growth regulators (BAP @ 4,5 and $\left.6 \mathrm{mg} \mathrm{l}^{1^{-1}}\right)$ either alone or in combination with NAA $\left(0.5 \mathrm{mg} \mathrm{l}^{-1}\right)$ and kinetin $\left(2 \mathrm{mg} \mathrm{l}^{-1}\right)$ to study the influence of growth regulators on multiplication rate. The data on number of multiple shoots, days for multiple shoot induction and micro shoot length were recorded. MS+BAP 6 $\mathrm{mg} \mathrm{l^{-1 }}+$ kinetin $2 \mathrm{mg}^{1^{-1}}$ recorded maximum number of multiple shoots (5.07). MS + BAP $6 \mathrm{mg} \mathrm{l}^{1^{-1}}$ recorded least days for multiple shoot induction (27.06 days) and highest micro shoot length $(6.73 \mathrm{~cm})$. Further to enhance multiplication best growth regulator combination (MS + BAP $6 \mathrm{mg}$ $\mathrm{l}^{-1}+$ Kinetin $\left.2 \mathrm{mg} \mathrm{l}^{-1}\right)$ along with different concentration of coconut water $(5,10$ and $15 \%)$ and casein hydrolysate $\left(100,200\right.$ and $\left.300 \mathrm{mg} \mathrm{l}^{-1}\right)$ were supplemented. MS + BAP $6 \mathrm{mg} \mathrm{l}^{-1}+$ kinetin 2

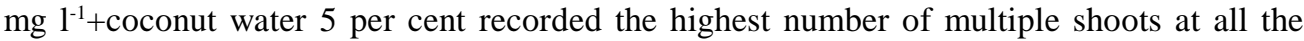
intervals of subculture (5.13). The best growth regulator combination (MS+BAP $6 \mathrm{mg} \mathrm{l}^{-1}+$ kinetin $\left.2 \mathrm{mg} \mathrm{l}^{-1}\right)$ along with B5 vitamins in specific to different thiamine concentration $(5,10$ and $15 \mathrm{mg} \mathrm{l}^{-1}$ ) for further multiplication were supplemented and $\mathrm{B}_{5}$ vitamins with thiamine combinations did not increase the multiplication rate. The degree of efficiency of shooting was found to be dependent on type of hormone.

KEY WORDS : Banana, Multiplication, BAP, Kinetin, Coconut water, Thiamine

HOW TO CITE THIS ARTICLE : Udaya, C.Y. Shalini, Porika, H.K., Sindhupriya, V. and Kumar, P. Prasanna (2016). Enhancing propagation efficiency of banana cv. MONTHAN (ABB) through micropropagation. Asian J. Hort., 11(1) : 141-145, DOI : 10.15740/HAS/TAJH/11.1/141-145. 